\title{
ARCTIC TROPOSPHERE CARBON DIOXIDE; LOW-ALTITUDE AIRCRAFT SAMPLING
}

Thomas A. Gosink ${ }^{1}$ and John J. Kelley²

Geophysical Institute ${ }^{1}$ Institute of Marine Science ${ }^{2}$ University of Alaska

Fairbanks, Alaska 99723

\section{ABSTRACT}

This paper presents data from low altitude (<4500 m) aircraft sampling for $\mathrm{CO}_{2}$ in the arctic atmosphere. The data cover the period from late spring to late summer when environmental changes at the tundra and sea ice are most pronounced. Results of the data analysis show the effect of regional sources and sinks for $\mathrm{CO}_{2}$ on the lower troposphere. The annual ice and open water zones of the Arctic Ocean covered by the flights transects appear to act as a potential sink for carbon dioxide.

$\mathrm{DOE} / \mathrm{EV} / 10429--5$

DE82 013681

MASTER

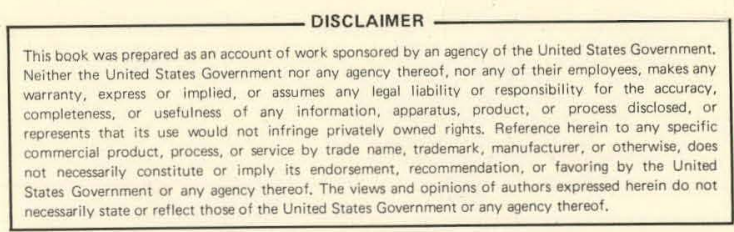

A. NOTICE

PORTIOAS OF THIS MEPORT ARE ILIEGIBLE.

It has baen regrodugad from the tesi avallablo

copy to permit the braodest possible avaliabiitity. 


\section{DISCLAIMER}

This report was prepared as an account of work sponsored by an agency of the United States Government. Neither the United States Government nor any agency Thereof, nor any of their employees, makes any warranty, express or implied, or assumes any legal liability or responsibility for the accuracy, completeness, or usefulness of any information, apparatus, product, or process disclosed, or represents that its use would not infringe privately owned rights. Reference herein to any specific commercial product, process, or service by trade name, trademark, manufacturer, or otherwise does not necessarily constitute or imply its endorsement, recommendation, or favoring by the United States Government or any agency thereof. The views and opinions of authors expressed herein do not necessarily state or reflect those of the United States Government or any agency thereof. 


\section{DISCLAIMER}

Portions of this document may be illegible in electronic image products. Images are produced from the best available original document. 
INTRODUCTION

Continuous infared analysis of carbon dioxide began at a clean air coastal site near Barrow, Alaska $\left(71.3^{\circ} \mathrm{N}, 156.7^{\circ} \mathrm{W}\right.$ ) In 1961 (Kelley, 1964, 1969 and 1973). Prior to this, seasonal and meridional variations were determined (Bolin and Keeling, 1963) from flask samples collected from aircraft operating at high altitude $(>5500 \mathrm{~m})$. As a result of a combination of data from surface station, ship, and aircraft samples (Bolin and Keeling, 1963) a distributional pattern emerged which showed that the annual variation was greatest in the atmosphere over arctic latitudes ( 12 ppm) and that minimal annual fluctuations in $\mathrm{CO}_{2}$ existed at the South Pole ( $I \mathrm{ppm}$ ). Both polar areas, however, reflected similar long-term trends in the gradual annual increase of $\mathrm{CO}_{2}$ in the atmosphere (Keeling et aZ., 1976) which persists to the present time.

Early attempts to assess the reasonability of the Barrow site as a background station for the long-term measurement of $\mathrm{CO}_{2}$ were made (Kelley, 1964) by joining in a cooperattve flask sampling program with the Scripps Institution of Oceanography (C. D. Keeling) which extended the collection of near surface sampled air from land based stations to far out over the Arctic Ocean at various occupied scientific stations on the ice. Associated with the same program, a limited number of samples were collected along transects at various inland sites and from low level aircraft flights. The results of the inland station data; collected mostly during late sumer and early fall, showed high variability in $\mathrm{CO}_{2}$ concentration which was presumed to be due to the effects of vegetation. Based on analyses of data for near-surface $\mathrm{CO}_{2}$ collected over a long period of time from the Barrow sites; ice stations and shlps, and spread over a wide latitudinal area in the arctic and subarctic regions, we directed some of our research effort to a systematic analysis of 
$\mathrm{CO}_{2}$ levels in the lower troposphere $(<4500 \mathrm{M})$ with emphasis on the seasonal ice zone of the Arctic Ocean and the tundra areas of the North Slope of Alaska. In addition, we hoped that the results of the low altitude aircraft data would compliment some of the implications to be found in the earlier high altitude data of Bolin and. Keeling (1963).

- The atmospheric $\mathrm{CO}_{2}$ concentration level begins to rise at Barrow, Alaska in late August, months before it does at mid-latitudes (late October) and reaches a worldwide high (for clean backgrounds) of about $340 \mathrm{ppm}$ in late May, months after northern hemispheric anthropogenic space heating has.ceased and lower latitude photosynthesis has begun. Furthermore, the late spring high is a resurgence rather than a continuous climb to that level, and the high levels persist for 1-2 weeks a few hundred $k m$ offshore as compared to Barrow (Kelley, 1973 and this work). Our estimates of the arctic sourcesink strengths for $\mathrm{CO}_{2}$, and for the role that annual sea ice plays in the winter-summer mixing ratio of atmospheric $\mathrm{CO}_{2}$, have been published elsewhere (Gosink and Kelley, 1982b). This article deals with the results of our low altitude aircraft atmospheric $\mathrm{CO}_{2}$ program, and shows the intensity of regional sources and sinks for $\mathrm{CO}_{2}$ on the lower troposphere.

\section{EXPERIMENTAL METHODS}

Transition from the exclusive use of infrared analysis to gas chromatography occurred over several years. By 1975, gas chromatographic.techniques were our primary analytical method and all measurements continued to be referred to $\mathrm{CO}_{2}$ standards provided by the Scripps Institution of Oceanugraphy (C. D. Keeling). The gas chromatographic procedure, standards and accuracy have been published elsewhere (Gosink and Kelley, 1982). The sample collection procedures are described below. 
A Naval Arctic Research Laboratory (Barrow, Alaska) Twin Otter aircraft was usually used to collect air samples. Air was conducted to a $250 \mathrm{ml}$ sampling flask via a small viton diaphragm air pump in the non-pressurized cabin at a rate of about 4-5 $\mathrm{l} / \mathrm{min}$. The air intake tubing (Teflon) was located on a strut well ahead of the engines. A twin-engine C117 aircraft was also occasionally used. The tubing was placed in one of the clean air scoops mounted above the fuselage forward of the engines. Sampling flight plans were established to fly 150 to $1000 \mathrm{~km}$ north of Barrow, Alaska. Samples were periodically collected at approximately $100 \mathrm{~m}$ altitude outbound. At the farthest point, a vertical profile was made from $40 \mathrm{~m}$ to $4500 \mathrm{~m}$ altitude. Samples taken inbound were made at $3200 \mathrm{~m}$ to a point usually about $80 \mathrm{~km}$ inland. Another set of samples was taken to establish a vertical profile over land.

Care was taken to flush the short section of glass tubing leading to the stopcock before the stopcock to the highly evacuated sample bulb was opened. After 1.5-2 minutes of flushing, the bulb was slightly pressurlzed before the stopcock was closed.

Some air samples were collected and held briefly under.slight positive pressure in teflon coated steel and glass (10 ml) gas tight syringes. It was necessary to employ oversize 0-rings under the teflon coated plunger in order to achieve a gas tight fit at low.temperatures. Analyses were completed within 24 hours; usually within 1 to: 6 hours. Samples held in these syringes were stable for 24-72 hours, depending on the particular syringe in question. The samples in the slightly pressurized gas sample bottle were stable for several weeks. All of our ambient air analyses over several years, using hand methods of readout of the stripchart recordings agreed with the NOAA/GMCC site daily observations by 1-2 ppm. We were both using the Index Scale of Reference. 
AIRCRAFT OVERFLIGHTS OF THE ARCTIC ICE AND TUNDRA

Figures la-d and Figures $1 e, f$ show horizontal and vertical profiles, respectively, of atmospheric carbon dioxide over land and over seasonal ice from late spring to late summer when the surface environmental changes are most pronounced. Other seasonal data show smaller or no horizontal and vertical change. The area sampled was always within a few hundred km from Point Barrow, Alaska.

There was a strong enrichment of $\mathrm{CO}_{2}$ over the predominently annual sea ice, and a noticeable depletion only $80 \mathrm{~km}$ inland on $26 \mathrm{June} 1977$ (Fig. 1a). The sea ice was nearly continuous and had only recently begun to melt about $150 \mathrm{~km}$ north of Point Barrow at that time. Thus, offshore $\mathrm{CO}_{2}$ evolution would have been high due to optimal opening of brine channels (Gosink and Kelley, 1982a, b). The tundra at that time was free of snow and ice, and was biologically active (i.e., soil respiration and photosynthesis were active). A.few weeks. later, $7 \mathrm{July}$ 1977, there was only a suggested trend in enrichment over the ocean portion of the north-south transect. The sea ice around Point Barrow was breaking up and melting out to $300 \mathrm{~km}$ by that time, thus low $\mathrm{PCO}_{2}$ surface waters may have influenced the local lower atmosphere at that time. There was, however, evidence for significant (10 ppm) enrichment at low altitudes offshore on $18 \mathrm{July} 1977$ for a flight $300 \mathrm{~km}$ east of Point Barrow. That flight maintained nearshore altitudes over melting sea Ice uf about $150 \mathrm{~m}$ drnpping to $15 \mathrm{~m} 100 \mathrm{~km}$ offshore over continuous annual ice which was only beginning to melt. The data for $20 \mathrm{July} 1977$ shows essentially constant oceanic atmospheric concentrations of $\mathrm{CO}_{2}$ out to nearly $1000 \mathrm{~km}$ north of Point Barrow. It is important to note that the $20 \mathrm{July} 1977$ flight was at $2 \mathrm{~km}$ altitude, whereas the previous two were conducted at $30 \mathrm{~m}$ over the ice. 
The data shown in Figure $1 b$ is for the same time period as Figure la, but a year later. In 1978 the ice had already brioken up several weeks earlier than the previous year. The data from these flights show an essentially constant low level atmospheric concentration of $\mathrm{CO}_{2}$ from inland $90 \mathrm{~km}$ south of Point Barrow to $300 \mathrm{~km}$ offshore to the north. The only exception was the early far inland data of 20 June 1978. There was a sharp depression in atmospheric $\mathrm{CO}_{2} 130 \mathrm{~km}$ inland, presumably due to the uptake of $\mathrm{CO}_{2}$ by the vegetation. The higher values $90 \mathrm{~km}$ inland may represent seasonal changes with respect to latitude when the surface was still thawing, and soil respiration was dominant. Similar data of slightly depressed $\mathrm{CO}_{2}$ values near the mountains and of higher levels of $\mathrm{CO}_{2}$ further north over the tundra, have been observed in the past at surface monitoring sites (Kelley, 1964). In early June of 1979 , the sea ice and tundra.were only beginning to thaw within $100 \mathrm{~km}$ of Point Barrow. The $\mathrm{CO}_{2}$ partial pressure was essentially constant at 340-341 ppm to $850 \mathrm{~km}$ north of Point Barrow, and only dropped 2-3 ppm, $200 \mathrm{~km}$ inland. Carbon monoxide at that time showed a more dramatic change and has been reported elsewhere (Gosink and Kelley, 1979).

Figure 1c shows the data from a flight transect during late summer (8-9 September 1978). Freezing had set in so that the intense biological activity in the tundra active layer had greatly diminished, yet the ground had not frozen and could still outgas without biological fixation of the $\mathrm{CO}_{2}$ (Coyne and Kelley, 1971). The oceans were nearly clear of all ice out to about $200 \mathrm{~km}$, and skim ice was visible in the many leads in the pack. ice. Low $\mathrm{PCO}_{2}$ water was still at the surface. This is in contrast to: the 27 June 1978 data (Fig. 1b) when biological activity was uniformly high. The far inland atmospheric concentrations of $\mathrm{CO}_{2}$ in this case were high and variable; and decreased northward to the coast where the $150-200 \mathrm{~km}$ of open $10 \mathrm{PCO}$ water appeared to influence lower troposphere. Our aircraft sample data near Point Barrow are in 
general agreement with the NOAA/GMCC recorded values at Barrow for the 2 days prior to and during the flight as shown by the small bar in Figure $1 c$. The surface winds were from a clean air northern (oceanic) sector. Winds aloft near Point Barrow usually have a westerly origin when the surface winds are from the north, and thus would have been influenced by the low $\mathrm{PCO}_{2}$ open waters of the Chukchi and northern Bering Seas. The air from the pack ice region. is clearly enriched in $\mathrm{CO}_{2}$ near the surface as shown in Figures $1 c$ and $1 f$. Figure lf is a vertical profile $320 \mathrm{~km}$ offshore for the 8 September 1978 flight (Fig. 1c).

Figure 1d presents data for a flight transect three weeks later after the tundra had frozen (30 September 1978). There had been almost continuous high winds and wave activity from the northeast and northwest. The surface sea water equilibrium $\mathrm{PCO}_{2}$ level remained surprisingly low at about $270 \mathrm{ppm}$ $20 \mathrm{~km}$ offshore. There was however, a definite but small (2-3 ppm) trend for enrichment $300 \mathrm{~km}$ offshore for the air at $3200 \mathrm{~m}$ which suggests possible enrichment by either new sea ice or high $\mathrm{PCO}_{2}$ surface waters farther out in the pack ice. Annual sea ice was forming in the leads in the pack ice, which was still $150 \mathrm{~km}$ offshore of the vicinity of Point Barrow. The offshore vertical gradient for the same flighl is shown in Figure.1e,

The strong vertical and horizontal changes in the atmospheric concentration of carbon dioxide as shown in Figure $1 \mathrm{~d}$ was not common. It does, however, shnw how local natural effects can influence the data at the clean air $\mathrm{CO}_{2}$ monitoring site. This incident prompted the studies by Peterson et al. (1980), and Halter and Peterson (1981) in which they re-investigated the Barrow, Alaska $\mathrm{CO}_{2}$ monitor data with respect to wind trajectory. Those studies substantiatcd the concepts of significant surface effects in the arctic as presented in this article. 
By 8 November 1978, the annual sea ice had reformed. There was high $\mathrm{PCO}_{2}$ water $(341 \mathrm{ppm})$ under the ice and a noticeable enrichment of $\mathrm{CO}_{2}$ in the air above the sea ice $180 \mathrm{~km}$ north of Barrow at that time. The air near $(30 \mathrm{~m})$ the surface $180 \mathrm{~km}$, north of Barrow had a concentration of approximately $340 \mathrm{ppm} \mathrm{CO} 2,80 \mathrm{~km}$ north it was $332 \mathrm{ppm}$ and at Barrow it was $327 \mathrm{ppm}$ ( 328 ppm according to the NOAA/GMCC data).

On five occasions, both north and south of Point Barrow, vertical profiles showed the layered presence of higher (6-10 ppm) $\mathrm{CO}_{2}$ near 1 km altitude. Occasionally, enrichment at $3 \mathrm{~km}$ was evident too. These data are not due to analytical error or contamination from the aircraft. A complementary study on aerosols (G. Shaw, University of Alaska, personal communication), on one flight showed that there were increases in aerosols at those same levels. These data suggest boundary layer entrapment. Ozone, which was also observed concurrently with $\mathrm{CO}_{2}$ on some flights, displayed a minimum in the $\mathrm{CO}_{2}$ maximum layers. On 16 January 1978, a low $\mathrm{CO}_{2}$ concentration rather than a $\mathrm{CO}_{2}$ maximum was evident at 600 meters. The ozone concentration in the $\mathrm{CO}_{2}$ minimum layer was also reversed in that it displayed a maximum.

The winter profiles were variable for the month of January 1978. There was generally a small trend for enrichment for $\mathrm{CO}_{2}$ near the surface. The air at altitude over the sea ice usually was more highly enriched compared to the over-land profile. Seventeen out of 20 flights over a two-year period did show clearly positive to slight enrichments in $\mathrm{CO}_{2}$ near the surface as compared to higher a.t.titudes.

\section{SUMALARY AND CONCLUSIONS}

Low altitude aircraft sampling $(<4500 \mathrm{~m})$ for atmospheric $\mathrm{CO}_{2}$ shows how intense ground level sources and sinks can, on occasion, modify the observations 
made on a fixed ground level station.(e.g., Fig. 1c). Layering effects are also seen on occasion as opposed to continuous gradients. The most important fact is that the annual ice and open water zones of the Arctic Ocean appear to be a significant source of $\mathrm{CO}_{2}$ in the winter and sink in the summer, which is further substantiated by high altitude flights (Bolin and Keeling, 1963), the low altitude data presented here and the trajectory analysis of Halter and Peterson (1981). Therefore, future atmospheric models should account for the natural sources and sink of $\mathrm{CO}_{2}$ in the arctic (Gosink and Kelley, 1982) and not consider them as essentially ice-sealed inert regions. 


\section{REFERENCES}

Bolin, B. and C. D. Keeling, Large-scale atmospheric mixing as deduced from seasonal and meridional variations of carbon dioxide, $J$. Geophys. Res., 68, 3899-3920, 1963.

Coyne, P. I. and J. J. Kelley, Release of carbon dioxide from the frozen soil to the arctic atmosphere, Nature $327,407-408, .1971$.

Gosink, T. A. and J. J. Kelley, Sources and sinks of carbon dioxide in arctic and subarctic regions, Submitted to J. Geophys. Res., 1982a.

Gosink, T. A. and J. J. Kelley, Annual sea ice: An air-sea gas exchange moderator, Submitted to J. Geophys. Res., 1982b.

Gosink, T. A. and J. J. Kelley, Carbon monoxide evolution from arctic surfaces during spring thaw, J. Geophys. Res., 84, 7041, 1979.

Keeling, C. D., R. B. Bocastow, A. E. Bainbridge, C. A. Ekdahl, Jr., P. R. Guenther, L. S. Waterma, J. F. S. Chin, Atmospheric carbon dioxide variations at Mauna Loa Observatory, Hawaii, TelZus, 28, 538, 1976.

Kelley, J. J., An analysis of carbon dioxide in the arctic atmosphere at Point Barrow, Alaska, 1961-1963, University of Washington, Dept. of Atmos. Sci., Technical Report, May 1964.

Kelley, J. J., An analysis of carbon dioxide in the arctic atmosphere at Barrow, Alaska, 1961-1967, University of Washington, Dept. of Atmos. Sci. Scientific Report 3, 1969.

Kelley, J. J., Dynamics of the exchange of carbon dioxide in arctic and subarctic regions, Inst. Mar. Sci., Univ. Alaska, Fairbanks, 1973.

Halter, B. and J. T. Peterson, On the variability of atmospheric carbon dioxide concentrations at Barrow, Alaska during summer, Atmos. Environ., $15,1391-1399,1981$.

Peterson, J. T., K. J. Hanson, B. Bodhaire and S. J. Ohmans, Dependence of $\mathrm{CO}_{2}$, aerosol, and ozone concentrations on wind direction at Barrow, Alaskà during winter, Geophys. Res. Lett.; 7, 349-352, 1980. 


\section{ACKNOWLEDGEMENTS}

We wish to thank the US Navy Office of Naval Research (Contract N0001476C-0331) for scientific support and logistical services at the Naval Arctic Research Laboratory, Barrow, Alaska. We also wish to gratefully acknowledge the support received from the US Department of Energy, Carbon Dioxide Research Program, under Contract No. 80EV10429. 

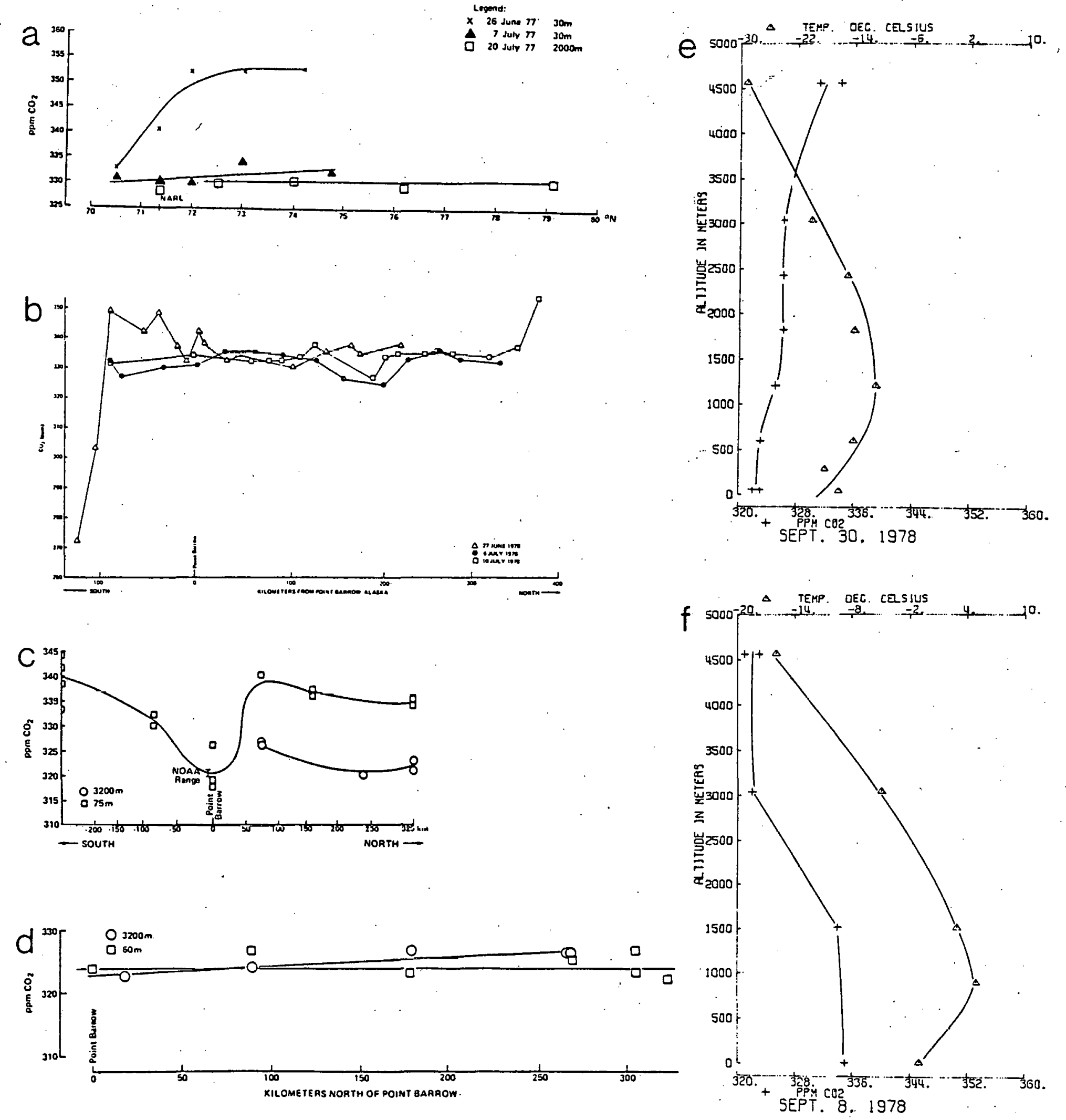


\section{FIGURE CAPTIONS}

Figure la. Horizontal profiles of atmospheric $\mathrm{CO}_{2}$ at low and high altitudes north and south of Point Barrow, Alaska, June-July 1977.

Figure 1b. Horizontal profile of atmospheric $\mathrm{CO}_{2}$ at low altitude north and south of Point Barrow, Alaska; June-July 1978.

Figure 1c. High and low altitude horizontal profiles at atmospheric $\mathrm{CO}_{2}$ north and south of Point Barrow, Alaska, 8-9. September 1978.

Figure 1d. High and low altitude horizontal profiles of atmospheric $\mathrm{CO}_{2}$ north of Point Barrow, Alaska 30 September 1978.

Figure le. Vertical profile of $\mathrm{CO}_{2}$ and temperature $320 \mathrm{~km}$ north or Point Barrow, Alaska, 8. September 1978.

Figure 1f. Vertical profile of $\mathrm{CO}_{2}$ and temperature $260 \mathrm{~km}$ north of Point Barrow, Alaska, 30 . September 1978. 